\title{
DEPARTMENT OF JUSTICE LITIGATION: EXTERNALIZING COSTSAND SEARCHING FOR SUBSIDIES
}

\author{
NICHOLASS. ZEPPOS*
}

\section{INTRODUCTION}

D epartment of J ustice ("DOJ") control over executive branch litigation is often debated in the context of broad themes in administrative law. ${ }^{1}$ A lthough important and illuminating, the central inquiry - to what extent is centralization of litigation an essential aspect of presidential control over executive branch policymaking-ignores the core aspect of the employment relationship between DOJ and its attorneys. It turns out that seemingly mundane aspects of the employment, such as wages, job responsibility, and recruitment of DOJ attorneys, raise intriguing and difficult questions of professional responsibility and institutional design.

This essay explores these ignored questions of DOJ compensation, recruiting, and staffing. The analysis starts with an obvious but largely unexplored question: Why do bright new attorneys forgo the salary offered by private law firms and instead choose to work for DOJ? I conclude that young attorneys choose DOJ because of the significant responsibility government practice provides. This explanation, however, prompts the more difficult question taken up in the second part of the paper: Why do the U nited States and its officers and agencies entrust complex, difficult, and profoundly important litigation to neophyte attorneys? A private client with substantial resources and important stakes in litigation would not choose to have a brief primarily drafted by or crucial oral argument conducted by a third-year associate, no matter how capable that associate is at that stage of his or her career.

\footnotetext{
Copyright (c) 1998 by L aw and Contemporary Problems

This essay is also available at http://www.law.duke.edu/journals/61L CPZeppos.

* Professor of Law, V anderbilt Law School. A ttorney, A ppellate Staff, Civil D ivision, U nited States Department of J ustice, 1982-87. I would like to thank Lisa Bressman, A ndy Daughety, Neal D evins, Barry Friedman, Steve H etcher, Nancy K ing, D on Langevoort, D oug L etter, B ob R asmussen, and J ennifer R einganum for their helpful comments. Janet $\mathrm{H}$ irt of the $\mathrm{V}$ anderbilt Law Library staff provided tireless assistance and thoughtful comments. I also would like to thank D ean K ent Syverud for supporting this project.

1. See Cornell W. Clayton, Government Lawyers 8-10 (1995); Neal Devins, Tempest in an Envelope: Reflections on the Bush White House's Failed Takeover of the U.S. Postal Service, 41 U CLA L. REV. 1035 (1994); Neal Devins, Unitariness and Independence: Solicitor G eneral Control of Independent A gency L itigation, 82 C A L. L. R E V. 255 (1994) [herinafter D evins, U nitariness].

2. Some of the ethical issues are discussed in G eoffrey P. M iller, Government $L$ awyers' $E$ thics in a System of Checks and B alances, 54 U . C HI. L. R E V. 1293 (1987).
} 
Without in any way suggesting that the government spends too little on legal fees, ${ }^{3}$ Part II points out that the government clearly conducts its business in a manner entirely different from clients with similar resources and important monetary consequences and matters of great principle at stake. A nalyzing the government's purchase of legal services provides new insights on the nearmonopoly DOJ maintains over litigation. A Ithough conventional wisdom describes the monopoly as a rational way of managing government policy, ${ }^{4}$ the artificial monopoly may instead be a mechanism for masking the resource shortfall that is the hallmark of government litigation. Finally, viewing litigation from the perspective of the government as a purchaser of legal services puts a different spin on conventional administrative law doctrines that operate with much potency and great frequency in litigation with the $U$ nited States. These doctrines can be understood as a hidden subsidy for government underpurchasing of legal services.

Part II of this essay also explores DOJ recruiting and concludes that DOJ must structure its litigation to draw top law school graduates for substantially lower wages. Part III explores how DOJ compensates in litigation for its use of neophyte attorneys and understaffing of cases, and discusses the market alternatives to DOJ's virtual monopoly over litigation. Part IV concludes that the market alternative has shortcomings not only for the agency, but for another institution with a strong interest in maintaining the DOJ monopoly, the federal judiciary.

\section{THE DOJ RECRUITMENT CONTRACT: TRADING WAGESAND WORKING A MENITIESFOR CONSUMPTION OF OTHER GOODS}

B efore examining why the government spends less on legal services than a private client, it is important to understand the nature of the employment "contract" entered into by the government and its lawyers. ${ }^{5}$ In short, how does the government recruit attorneys to work for DOJ when the attorneys could make substantially more money in private practice? Competition for jobs in

3. For fiscal year 1998 , D OJ requested $\$ 19$ billion, a $4.9 \%$ increase over the prior year. See D OJ Increases Reflected in Judiciary Workload, 29 THE THIRD BRANCH 5 (A pril 1997). However, only a fraction of these resources are devoted to litigation. See id.

4. On the standard arguments for the DOJ monopoly and persuasive critiques see CLA YTON, sUpra note 1; D evins, U nitariness, supra note 1.

5. My primary focus is the hiring of attorneys through D OJ 's H onors Program which applies only to those directly out of clerkships or law school. A lthough some of my arguments might apply to lateral hires D OJ makes, the lateral market is sufficiently different to be excluded from my analysis. For example, lateral hires may choose DOJ over a private firm for more explicit tradeoffs between money, leisure, and family. See generally GARY S. BECKER, A TREATISE ON THE FAMILY (1991). For the first practice job out of law school these qualities may not be as central to career choice. Nor can DOJ rely solely on those factors for its new hires to make a long-term career choice of D OJ. R eflecting the fact that entry hires typically move on to other jobs, DOJ explicitly demands Honors hires to make a three-year commitment. See U NITED STA TES DEPARTMENT OF JUSTICE LEGAL A CTIVITIES 1997-98, at 2 [hereinafter DOJ LEGAL A CTIVITIES]. 
DOJ is quite intense, ${ }^{6}$ and the academic credentials DOJ lawyers possess are comparable to those of lawyers who work for the most elite firms in the nation. ${ }^{7}$ Some scholars hypothesize that DOJ is successful in recruiting these attorneys at least in part because the attorneys trade-off present salary for invaluable career experience that will pay dividends in the future. ${ }^{8}$ A better explanation is instead that the young attorney trades money for job responsibility and career satisfaction.

\section{A. Choosing D OJ : Consumption Not Investment}

D OJ attorneys enter at a pay level of $\$ 38,330$, a GS-11 grade. If, as is common, the attorney has done a judicial clerkship, the entry-level pay is typically $\$ 45,939$. ${ }^{9} \quad$ This salary is considerably below associate salaries at law firms throughout the country. Starting with firms in Washington, D.C. with more than 100 lawyers- the obvious point of comparison for attorneys who choose D OJ - the mean 1997 salary for new associates was approximately $\$ 75,000{ }^{10}$ Some may also receive a clerkship bonus, which for Supreme Court clerks can be $\$ 75,000$. O ther cities show comparable disparities between DOJ and private law firms. ${ }^{11}$ The approximate difference of $\$ 35,000$ is in no sense insignificant and demands an explanation.

One of the most common explanations offered is that young attorneys choose D OJ because of the excellent litigation experience they receive. ${ }^{12}$ This

6. See id. at 11 (noting that hiring for the A ttorney General's H onors Program is "highly competitive").

7. See donald L. Horowitz, The Jurocracy: Government lawyers, agency PROGRAMS, AND J UDICIA L DECISIONS 27-34 (1977); M ichael Herz, The A ttorney Particular: G overnmental Role of the A gency General Counsel, in CLAYTON, supra note 1, at 160. B ased on data collected over the last 10 years, of the 1,600 attorneys hired through the Honors Program, $40 \%$ had judicial clerkships, $65 \%$ were on law review, and $80 \%$ were in the top third of their law school class. See Telephone Interview by J anet Hirt with Paula Vickers, DOJ employee (A ug. 20, 1998). For a more general discussion of early efforts to recruit high quality young law graduates into government service, see Robert G. GlenNon, The ICONOCLASt as Reformer: Jerome Frank's Impact on A MERICAN LA W 70-73 (1985).

8. See HOROWITZ, supra note 7, at 27 (noting that new attorneys use DOJ for experience and then move on to other jobs). Two other possible explanations for the choice of D OJ over the private law firm are not as compelling. First, some may choose DOJ as a stepping stone to non-firm jobs such as law teaching; the $\mathrm{O}$ ffice of L egal Counsel, the Office of the Solicitor G eneral, and A ppellate Staffs of litigating divisions, have served as excellent stepping stones. But those offices are far too small (particularly given the number of attorneys who choose to work elsewhere in D OJ ) to provide a strong basis for the "stepping stone" theory. A second theory is that some attorneys choose DOJ for the shorter hours and leisure time. This theory is far better at explaining why attorneys enter DOJ as laterals or remain at D OJ for their entire career. But for entering attorneys D OJ proves to be quite demanding. The responsibility for one's own cases and enjoyment of the work is likely to make the hours long.

9. These figures are for 1997. See D OJ LEGAL A CTIVITIES, supra note 5, at 12. Federal law authorizes a small locality adjustment to compensate attorneys who reside in cities with higher costs of living.

10. See national a ssociation for la w Placement, Class of 1997 employment Report \& SALARY SURVEY 58 (1998) [hereinafter 1997 NA LP REPORT].

11. New Y ork associate salaries now exceed $\$ 100,000$, and Chicago is near $\$ 90,000$. See Frances A . M cM orris, R ookie L awyers See Pay Soar A bove $\$ 100,000$, W A LL ST. J ., A pr. 29, 1998, at B 1.

12. See HOROWITZ, supra note 7, at 27, 29-30. 
experience then can be capitalized on later when the attorney enters private practice. $V$ iewed in this way, the pay cut that attorneys take by going to DOJ is simply an additional educational investment made by the young attorneytantamount to an additional "tuition" payment made for post-law school training. ${ }^{13}$

No doubt DOJ attorneys do acquire valuable experience from government practice. $Y$ et the argument that they trade-off the higher salaries at private firms for this experience is not without problems. First, it fails to integrate the relatively short tenure track of many DOJ attorneys. ${ }^{14}$ The DOJ Honors Program requires recruits to make three-year commitments to $D O J$, a rule that is broken but rarely enforced. This explicit norm suggests that many young D OJ attorneys would otherwise leave in less than three years. B ut is that really sufficient time to gain the valuable "experience" that compensates for the income losses? Probably not. To be sure, in many areas of D OJ litigation, cases move very quickly, often being resolved without discovery on a motion for injunction. But for matters that go to trial-many civil fraud cases, tort cases, and discrimination cases- a tenure short of three years hardly seems sufficient to gain extensive litigation experience. Moreover, while even new DOJ attorneys are given interesting cases, the highest profile and most significant cases are assigned to attorneys who have been at DOJ for more than two years. In short, the learning curve-while perhaps steep for D OJ attorneys-cannot provide a sound basis for the salary/experience argument.

The second problem with the experience argument is that it suggests that young attorneys can get better litigation training at $D 0 \mathrm{~J}$ than at a private firm and that their firms will later compensate them for this training. This is a somewhat curious argument. First, DOJ's on-the-job training bears little resemblance to what occurs in private firms. A t large, private firms' lawyers are slowly given major responsibility; ${ }^{15}$ and while competitive forces have perhaps led to some changes in the delivery of legal services, they apparently have not produced dramatic results. ${ }^{16}$ To be sure, the economics of large firm practice

13. See Gary S. BeCKer, Human CAPITAL: A TheORETICAL AND EMPIRICAL ANALYSIS WITH Special Reference to EduCAtion (1964); Walter W. MCMAHON, InVEStMent in Higher EDUCATION (1974). Some have made a similar claim in the context of evaluating associate salaries. Leibowitz and Tollison argue that associate salaries are relatively low and that after receiving firmspecific training associates recoup income upon entry to the partnership. See A rleen Leibowitz \& R obert Tollison, L earning and E arning in L aw Firms, 7 J. L E GA L STU D. 65 (1978).

14. See HOROWITZ, supra note 7, at 27-32 (discussing rapid D O) turnover among younger attorneys). R ecent developments may have dated $\mathrm{H}$ orowitz's findings and altered the hiring landscape at DOJ. See also DOJ LEGAL A CTIVITIES, supra note 5, at 2 (discussing the three-year commitment). B oth dissatisfaction in private practice and the increasing selectivity of partnership decisions have led to active efforts by D OJ to make lateral hires. E ven here, however, and perhaps to a greater extent, the salary differences between DOJ and private practice are significant. The top salary for a career D OJ attorney is less than $\$ 100,000$. Seeid. at $v, 8$.

15. See Robert L. Nelson, PARTners With POWER 180 (1988) (“Whichever field they practice in, associates less frequently perform the 'more responsible' tasks of law practice.").

16. See Paul M. Barrett, Companies Make Little Headway Curbing Lawyers' Billable Hours, W A LL ST. J ., D ec. 2, 1996, at B 11; M ilo G eylin, G oing First Class-Soaring L egal Expense: M otorola 
are quite different from government practice and drive how large law firms staff cases. Moreover, the private law firm and the client it represents have compelling reasons to invest substantial resources in important litigation. In other words, both the law firm and the client must directly internalize the cost of litigation errors-certainly more than D OJ and its clients. These differences suggest that the DOJ method of "training" is less than optimal. Indeed, if we were to require $D O J$ to internalize these costs there might well be a change in how it staffs its cases.

Finally, the D OJ experience argument is faulty because it never answers the central question: D oes the D OJ lawyer get a return of the salary differential in later firm compensation? ${ }^{17}$ For a number of reasons the answer seems to be no. First, insofar as the DOJ attorney enters as an associate with a lockstep compensation system, her pay will be identical to attorneys who joined the firm immediately after law school or after serving as judicial law clerks. ${ }^{18}$ Second, D OJ recruits do not seem to earn more as partners to make up for the pay differential. ${ }^{19}$ The associates who entered private practice right after law school, instead of going first to DOJ, are likely to have made contacts with important clients and done work for influential partners during their extra years at their firms. M oreover, the finding that seniority is a key determinant of income in a large law firm further undermines any theory of income recapture. ${ }^{20}$ Thus, it seems quite likely that the D OJ attorney forever gives up the pay differential. ${ }^{21}$

Bemoans It but Runs a Big Tab, W A LL ST. J ., Oct. 5, 1994, at A 1; Testing Task-Based Billing, Cor P. Couns. MAG. 100 (1997).

17. One argument may be that young attorneys use DOJ experience to get hired by an elite firm that would not have hired them on the basis of their law school academic record. This argument is undercut by the fact that D OJ hires from the same pool of elite law graduates as do the top private firms. A Ithough beyond the scope of this essay, such a hypothesis may have more validity applied to a lawyer employed by a federal agency who seeks to move into private practice. See Herz, supra note 7, at 160 (contrasting backgrounds and prestige levels of D OJ and agency lawyers).

18. On the general debate over seniority versus productivity-based compensation, see R onald J. Gilson \& R obert H. M nookin, Sharing A mong the Human Capitalists: A $\mathrm{n}$ conomic Inquiry into the Corporate Law Firm and H ow Partners Split Profits, 37 STA N. L. REV. 313 (1985); B ruce D. H eintz, N ew Trends in Partner Profit D istribution, LE GA L E CON., N ov./D ec. 1981, at 9; see also NELSON, supra note 15, at 193 (noting that differences between associates' salaries are "relatively insignificant"). For an interesting discussion of non-seniority based compensation, see W ard B ower, Can a Partner's Value B e M easured? (visited Sept. 14, 1998) <http://www.altmanweil.com/publications/articles>.

19. Nelson's data on partner income refutes the claim that partners' income "can be explained by differences in skills that lawyers accumulate over the course of their careers in firms." NELSON, supra note 15, at 201. Nelson's data is of course a bit dated, and certainly competitive pressures have prompted law firms to rethink how partners are compensated. Nonetheless, more recent studies show that "there remains a strong correlation between years of experience and compensation that is driven is part by economics (higher billing rates and greater efficiency of experienced fee producers)." COMPENSA TION PLANS FOR LA W FIRM S 11 (James D. Cotterman ed., 2d ed. 1995); see also id. at 65 (noting that first few years of associate compensation are lockstep); id. at 73-74 (noting difficulty in administering a compensation system tied to individual performance). The recent data may reflect the winnowing of senior unproductive lawyers from the partnership.

20. Seeid. at 11.

21. A nother argument may be that D OJ lawyers who switch to private firms get more responsibility when they join the firm, especially on in-court litigation. This argument depends upon those who worked at the firm throughout conceding that their training leaves them less capable than D OJ laterals to handle certain litigation matters. O bviously there are cognitive barriers to this group of lawyers 
Therefore, to understand the income loss by the person who chooses to work for D OJ instead of entering private practice, we should view it not as an investment but as non-pecuniary compensation, or what some may view as consumption. People forego income for many reasons, including more leisure time or simply choosing to get non-pecuniary value out of the time. In other words, just as one can spend $\$ 20,000$ on a new car or invest the same money in the stock market, a person choosing a job may decide to take a job that is lower paying but provides them other benefits. ${ }^{22}$ This is the more likely explanation for choosing to work for DOJ; this is at the heart of the bargain that DOJ strikes with its young attorneys. Consumption, not investment, is the motivation.

\section{B. Trading M oney for R esponsibility, Intellectual Stimulation, and A utonomy}

The attorney trades off many things by choosing $D 0$ J over private practice. A part from the financial tradeoff, the DOJ attorney is giving up amenities, staff, and secretarial support. However, the offsets are many and obvious. First is the major responsibility DOJ gives to young attorneys. The case load and shortage of attorneys mandates that young attorneys be given major responsibility for significant litigation. ${ }^{23}$ While my experience was limited to appellate work, it is not atypical. Within four years, I had argued twenty-one cases (two en banc), including six in the D.C. Circuit.

adopting such a view. See D onald C. Langevoort, Ego, Human B ehavior, and Law, 81 VA. L. REV. 853 (1995). O ne exception may be the relatively recent movement of people from the Office of the Solicitor $\mathrm{G}$ eneral into private firms to form Supreme Court practice groups. It may be that private firms recognize (as they no doubt do with Supreme Court clerks) the value of this experience and market this as a specialized practice to present and prospective clients. Of course, insofar as these Solicitor $G$ eneral lawyers have entered as partners they have more status in the firm than the D OJ lawyers I am focusing on who typically join a firm as an associate.

22. For an extended analysis of this approach to appellate judging, see RICHARD A. POSNER, O VER COM ING LA W 135-44 (1995). The substitution of income for non-pecuniary job characteristics is discussed in B.K. A trostic, The D emand for L eisure and Nonpecuniary J ob Characteristics, 72 A M ER. ECON. REV. 428 (1982).

23. DOJ clearly markets this aspect of the job. See DOJ LEGAL A CTIVITIES, supra note 5, at 10 ("The [DOJ] offers an attorney experience that cannot be duplicated anywhere else.... [E] ]ven new attorneys play significant roles in our litigation effort almost from the moment they walk in the door."); id. at 11 ("H onors Program attorneys typically are entrusted with an extraordinarily high level of responsibility very early in their careers."); id. at 37 ("The Civil D ivision's demanding caseload provides new attorneys with immediate opportunities to handle significant litigation. U nlike his or her counterpart in the private sector, the Civil Division attorney receives substantial responsibilities for cases from the start."). Similar claims are made by other litigating divisions. See id. at 41 (Civil Rights Division); id. at 58-59 (Tax D ivision); id. at 54 (E nvironmental Division).

This must be contrasted with reports that one of the major complaints of junior associates at private firms is the lack of responsibility for important matters. See NALP FOUNDATION FOR RESEARCH \& EDUCATION, KEEPING THE KEEPERS: STRATEGIES FOR A SSOCIATE RETENTION IN TIMES OF A TTRITION 14, 34 (1998) (tying job satisfaction to substantial responsibility and noting that associates complain about lack of challenging and important assignments and client contact); cf. M ark L. Byers, Career Choice and Satisfaction in the Legal Profession, 12 CAREER PLANNING \& A DULT DEV.J.6 (1996) (highlighting importance of control over work in measuring job satisfaction). 
Second, the issues D OJ attorneys litigate are of great intellectual interest. ${ }^{24}$ For example, in many civil cases litigated by DOJ the issues are purely legal and involve no discovery. Much of DOJ civil litigation involves the defense of agency action, which under well-established doctrine is reviewed on the agency record, not on a record developed in district court. ${ }^{25}$ Indeed, many agency decisions are reviewed in the courts of appeals; therefore factual disputes are quite rare. $^{26}$

The issues DOJ litigates are also intellectually challenging because they arise out of the exercise of governmental and political power. When the President, an agency, or Congress acts on a policy initiative, the actions are often at the outer perimeter of constitutional and legal authority. A s commentators have long recognized, political and social issues are almost immediately transformed into legal issues. ${ }^{27}$ W ith the dominant role played by the government in all reaches of economic, social, and political life, the U nited States will be a litigant in these controversies. It is not often that a young attorney can work consistently on such challenging intellectual issues. ${ }^{28}$

The third trade-off for income, autonomy for young lawyers, arises because DOJ offers independence from both extensive hierarchy within the Department and from outside client control. N ew attorneys in law firms tend to work within a well-defined hierarchy of senior associates, junior partners, and senior partners, with responsibility and control parceled out within the hierarchy. ${ }^{29}$ The hierarchy at DOJ, while also appearing well-defined and extensive, actually does little to impinge on the young attorney's autonomy. M ost cases are staffed with one senior "reviewer" who signs off on all major written filings. It is extraordinarily rare for review to occur above that level, and it is almost unheard of for extensive review to be conducted by an assistant attorney general or one of her deputies.

Perhaps more important is the independence from clients characteristic of DOJ. DOJ has a virtual monopoly over litigation; it is impossible for most

24. Intellectual challenge and stimulation are, according to one study, the most commonly cited reason for choosing a legal career. See Byers, supra note 23.

25. See Camp v. Pitts, 411 U .S. 138 (1973).

26. See Thunder Basin Coal Co. v. Reich, 510 U .S. 200 (1994); Reno v. Catholic Soc. Servs., 509 U .S. 630 (1993).

27. SeeA lexisde Tocqueville, Democracy In A merica 280 (J .P. Mayer ed., 1969) (1835).

28. A gain, DOJ exploits this in its materials. See DOJ LEGAL A CTIVITIES, supra note 5, at 10. ("[T] $]$ he important nature of the D epartment's work in all organizations ensures that its lawyers frequently handle cases of national significance, often forging new areas of the law."). I am assuming (fairly, I think) that the market in DOJ job-related information is efficient, thus constraining claims made in recruiting materials. This intellectual challenge must be considered against the backdrop of the academic records compiled by D OJ attorneys and their cohorts in private law firms. Typically they have outstanding academic records from both undergraduate education and law school. See HOR OWITZ, supra note 7, at 29-30. It should thus not be surprising that they would put a premium on intellectual challenge and stimulation. Cf. L ewis A . Kornhauser \& R ichard L. R evesz, L egal E ducation and E ntry into the L egal Profession: The R ole of Race, G ender, and E ducational D ebt, 70 N.Y.U . L. REV . 829, 833 (1995) (noting that public employment and those with high law school grades are correlated).

29. See NELSON, supra note 15 , at 188 . 
agencies to fire their lawyers or shop around for a new "law firm." ${ }^{30}$ A lthough D OJ attorneys certainly owe basic duties of professionalism and civility to clients, ${ }^{31}$ the monopoly changes the relationship in important and subtle ways. At the most elementary level, the DOJ attorney need not worry as much about pleasing or cultivating clients. M ore profoundly, the DOJ attorney has a fundamentally different duty of loyalty to her client. Particularly as one moves up through the federal court system, the legal positions of government agencies represented by DOJ are carefully reviewed, scrutinized, criticized, and often outright rejected. ${ }^{32}$ Thus, the relationship between DOJ attorneys and their client agencies is often adversarial, even on occasion empowering the D OJ attorneys to act in a quasi-adjudicative role. ${ }^{33}$ This effect is most apparent at the appeal, rehearing en banc, and certiorari stages of litigation. G enerally, an agency may not appeal or seek rehearing or certiorari without the permission of the Solicitor $\mathrm{G}$ eneral, ${ }^{34}$ who relies extensively on memoranda generated by both his staff and the appellate staffs of the DOJ litigating divisions. Oftentimes, these DOJ attorneys write memoranda highly critical of the agency's actions and its legal arguments, and recommend that the Solicitor $G$ eneral simply put an end to the matter or tell the agency its position is indefensible. ${ }^{35}$ The experience is not only a heady one for DOJ attorneys, but it fulfills a core aspect of professional fulfillment and prestige-independence from client pressures.

DOJ's control over its client agencies and the clients' control over private attorneys should not be overstated. Certainly there are instances of the Solicitor $G$ eneral acquiescing in the agency's litigation wishes (particularly when the loss will affect only that agency), of outright capitulation by the Solicitor General, or of agencies using political power to overwhelm DOJ. ${ }^{36}$ A nd surely in the private sector good lawyers sometimes tell their clients that "enough is enough." Y et even if the DOJ and private models of client control are not at opposite poles of a spectrum, they are clearly found far apart.

Interestingly, what is not traded-off by the DOJ lawyer is prestige. ${ }^{37}$ Indeed, the qualities that compensate the DOJ attorney for loss of income are

30. The DOJ monopoly is extensively analyzed in Devins, Unitariness, supra note 1, at 182-84. The statutory source of D OJ litigation authority is 28 U .S.C. $\S 516$ (1994).

31. It is true that D OJ faces no potential malpractice liability for any errors it might make on behalf of its client agencies. Y et this is unlikely to affect how DOJ handles cases. Other large institutional clients tend not to use malpractice actions as a means of controlling their lawyers. See D avid B. Wilkins, Who Should Regulate L awyers, 105 H A R V. L. REV. 801, 832 (1992).

32. See HOROWITZ, supra note 7, at 45; Wade H. M CC ree, J r., The Solicitor G eneral and His Client, 59 W A SH. U. L.Q. 337, 341 (1981). Lincoln Caplan's muckraking account of the Solicitor G eneral's O ffice documents the role in a number of high-profile cases. See L INCOLN CA PLAN, THE TENTH J USTICE: The SOLICITOR GENERA L AND THE R ULE OF LA W (1987). The scrutiny occurs routinely in less controversial cases.

33. See HOROWITZ, supra note 7, at 47.

34. See 28 C.F.R. $\S 0.20$ (1997). For a discussion of how agencies with independent litigation authority exercise their power, see D evins, U nitariness, supra note 1.

35. See CA PLA N, supra note 32 , at 18, 62-64.

36. Seeid.

37. See HorowItz, supra note 7, at 22; Herz, supra note 7, at 160. 
usually the same qualities that are considered in measuring job prestige. In their pioneering work on the legal profession, John Heinz and E dward Laumann attempt to identify the determinants of status and prestige in the different jobs lawyers hold. ${ }^{38}$ They conclude that the nature of the client-corporate versus individual - is a key variable in measuring job prestige. A lthough the $U$ nited States does not fall squarely into the $\mathrm{H}$ einz and Laumann two hemisphere model, it bears attributes similar to the large corporate clients upon which $\mathrm{Heinz}$ and Laumann focus. Indeed, in its ability to exercise significant power over the economy, the government exceeds the key indicator that $\mathrm{H}$ einz and Laumann use in explaining the link between the prestige of the bar and the corporate client. ${ }^{39}$ On other factors that $\mathrm{H}$ einz and Laumann explore in their analysis of job prestige-intellectual challenge and job autonomy ${ }^{40}-$ presumably D OJ lawyers would surpass even the elite corporate bar.

This aspect of the DOJ contract with its young attorneys is not without its downside risks, and these risks pose the question explored in the remainder of this essay: Why does the government entrust young attorneys with complex, important, and difficult cases-cases that would be heavily staffed if they were to arise in a private law firm? No doubt part of the answer comes from the recruitment policy outlined above. But that is only a partial explanation. It explains the terms of employment that DOJ must offer to recruit talented young lawyers. L eft unanswered is who bears any of the costs of this staffing and recruitment policy, and whether there are hidden subsidies that offset the disadvantages that arise in litigation from the D OJ contract with its lawyers.

III

\section{Explanations For Government Purchasing of Legal Services from THE DEPARTMENT OF JUSTICE}

A lthough DOJ may suffer a disadvantage in litigation, it manages to overcome it in a number of ways. These offsets take a number of different forms, sometimes operating almost as a direct subsidy; other times in a far more subtle fashion. In either case, however, the effect is the same: to compensate for D O J's employment of neophyte attorneys.

\section{A. O ffsetting the $D$ isadvantages to the $G$ overnment}

A lthough the private market may not allocate both an optimal price and staffing level for legal services, the prevalence of different practices- even after years of corporate retrenchment in legal fees-suggests that the government's way of litigating puts it at a disadvantage. ${ }^{41}$ Some explanations are offered be-

38. See JOHn P. Heinz \& Edward O. Laumann, Chicago LaWyers: The Social StRUCTURE OF THE BAR 330-74 (1982).

39. See id. at 330-31.

40. See id. at 102-03.

41. M ost government civil cases are handled by one staff attorney and one supervisor. The supervisors tend to be either DOJ career attorneys or those with more than 10 years at D OJ. W hile these 
low for how the government and the legal system offset this disadvantage through indirect subsidies.

1. A Case Selection Hypothesis. A lawyer may be able to offset a disadvantage in litigation by selecting cases with the strongest arguments. E ven if a party's litigation resources (including experience and staffing) are disproportionate, there is a point at which the resource advantage is of marginal or no benefit because of the merits of the case. E ven the best lawyer with the most resources cannot turn a group of weak cases into winners. The under-resourced attorney can develop a strong portfolio only if a certain condition is met: $\mathrm{He}$ or she must have a monopoly over the clients' ability to get access to the courts. O nly in that way can the lawyer make sure that the weaker cases are not pursued.

This monopoly condition approximates the situation DOJ has established with most government agencies. ${ }^{43}$ The DOJ monopoly allows its attorneys to focus on cases that have a higher chance of prevailing and, accordingly, diminishes the significance of the resource and experience disparity it faces in litigation. ${ }^{44}$ Particularly at the court of appeals and certiorari stage, the D OJ success rates are quite high, far higher than other litigants. ${ }^{45}$ It may be that if DOJ acted more like a private law firm, and had to behave as if its client-agencies could hire different counsel to press their cases, the resource and experience disadvantages D OJ works under would be more evident.

It nonetheless may be uncertain whether removal of the monopoly would affect the success rate of DOJ litigators. A s suggested above, the rate should decline because DOJ would have to acquiesce in more questionable client litigation decisions if it faced the loss of the client. DOJ attorneys and the extant literature also suggest another reason for this decline. DOJ 's careful selection

supervisors can be compared to firm partners, in fact they function quite differently. They tend not to be stratified themselves, and it is highly unusual to have more than one working on a case. A Iso, their workload precludes intensive review and rewriting of briefs, and they cannot rely upon a junior partner or senior associate to perform those functions.

42. This is subject to the caveat that "win" rates not be propped up only by taking the easiest and least significant cases. See RICHARD A. POSNER, E CONOMIC A NA LY SIS OF LA W 566-68 (3d ed. 1986) (discussing agency case selection).

43. See HOROWITZ, supra note 7, at 5 .

44. On litigation expenditures, see R obert Cooter \& Daniel R ubinfeld, E conomic A nalysis of $L e-$ gal Disputes and Their Resolution, 27 J. ECON. LITERATURE 1067 (1989); A very K atz, J udicial Decisionmaking and L itigation Expenditure, 8 INT'L REV.L.\& E CON. 127 (1988).

45. See CA PLAN, supra note 32, at 4 (discussing success rates before the Supreme Court). U nfortunately, it has proven quite difficult to obtain reversal rates for the government in court of appeals litigation. For 1997, the overall reversal rate in the court of appeals for non-prisoner civil cases involving the U nited States was $12.1 \%$, meaning of course, that $87.9 \%$ were affirmed. See JUDICIAL BU SINE SS OF THE U NITED STA TES COURTS, tbl. B -5 (visited M ay 14, 1998) <http://www.uscourts.gov/ judicial_business/contents.html>. There has been a dramatic drop in the overall reversal rate from 1960 to 1995 . See RICHARD A. POSNER, ThE FEDERAL COURTS: ChALLENGE AND REFORM 70-71 (1996) (noting a rate of $9.6 \%$ in 1995). Extrapolating from data provided to me, the reversal rate of the A ppellate Staff of the Civil Division for 1997 was 62\%. See U.S. DEPARTMENT OF JUSTICE, A PPELLATE BRANCH RESULTSAND DISPOSITIONSIN 1997, at 1-2 (on file with author). 
of cases and monitoring of legal arguments creates goodwill with the courts. ${ }^{46}$ Courts know that if DOJ is pursuing the matter (particularly on appeal or certiorari), the stakes must be high and the legal arguments generally sound. If the DOJ monopoly were removed, the agencies would no longer be subject to the same constraints and would press weak arguments, in perhaps insignificant cases, leading to a system-wide loss in credibility. ${ }^{47}$ This in turn would lead to a reduction in success because agencies would deplete the pool of goodwill generated by the DOJ monopoly.

$V$ iewed in this light, the goodwill created by DOJ is a kind of public good that is subject to a fairly typical tragedy of the commons. ${ }^{48}$ O nce the goodwill is created, all agencies will have an incentive to use it, and it will be hard to charge the agencies that do use it. Without means to exclude or charge, the goodwill will soon be over-consumed. The solution to the tragedy is obvious: install DOJ as the gatekeeper to the commons.

N otice that the tragedy of the commons story told by D OJ attorneys-most frequently by the Solicitor $\mathrm{G}$ eneral's $\mathrm{O}$ ffice $^{49}$ - along with its companion strategy of careful case screening, support the high DOJ success rate. DOJ attorneys go to court with cases rigorously screened at least at the appellate stage and subject to review at the trial level as well. The artificial scarcity of DOJ filings also creates goodwill with the courts, making the courts more receptive to the seriousness of the policy consequences advanced by DOJ and predisposed to take the legal arguments seriously. ${ }^{50}$

46. This is most evident in the Supreme Court. See CAPLAN, supra note 32, at 18. A Ithough Caplan's focus is almost primarily the Supreme Court, the Solicitor G eneral performs an equally important function screening cases the U nited States appeals to the courts of appeals. See id. at 6.

47. See id. at 19-24, 76 (discussing link between goodwill and litigating success of the Solicitor General before the Supreme Court). In United States v. M endoza, 464 U .S. 154 (1984), the Supreme Court explicitly relied upon this screening function in both the Courts of A ppeals and the Supreme Court-and its system-wide benefits-as a basis for holding that the government is not subject to nonmutual collateral estoppel. The Court cited the government's brief which highlighted the benefits provided by screening. See B rief for the U nited States, U nited States v. Mendoza, 464 U .S. 154 (1984) (No. 82-849) ("The government's practice of selective pursuit of appellate review benefits the public interest and facilitates sound judicial management."). The Court has reiterated the importance of this screening function by the Solicitor G eneral, rebuking him when he cedes some of his authority. See Federal E lection Comm'n v. NR A Political V ictory Fund, 513 U .S. 88, 93, 98-99 (1994); U nited States v. Providence J ournal Co., 485 U .S. 693, 701 (1988).

E ven in those cases where the Solicitor $\mathrm{G}$ eneral has the least discretion-where he is duty bound to defend the constitutionality of congressional enactments, see Pub. L. No. 96-132, § 21 (codified at 28 U.S.C. § 519 (1994)), discussed in CA PLA N, supra note 32, at 132-his ability to offer a narrowing interpretation of the law confers upon him substantial ability to retain his reputation for forthrightness with the Court. See U nited States v. X-Citement Video, Inc., 513 U.S. 64 (1994) (offering narrow reading of statute regulating sexually explicit material to withstand First $A$ mendment challenge).

48. See G arrett H ardin, The Tragedy of the Commons, 162 SCIE NCE 1243 (1968).

49. See CA PLA N, supra note 32 , at 21-24, 76 .

50. Some of my colleagues expressed shock and disbelief at the implication that courts were "biased" in favor of the government. M y claim is not one of bias, but instead an increase in credibility that is given a litigant who undertakes certain functions that serve the institutional interests of the court in allocation of judicial resources. In this respect goodwill is a good dispensed by courts to all (including private lawyers or law firms) with certain professional standards. The D OJ monopoly simply allows the government to earn more than private firms. 
2. Negative Externalities Generated by the DOJ Monopoly. If the DOJ monopoly does indeed opperate as described above, why do agencies tolerate the resulting disadvantage? Two negative externalities generated by the DOJ monopoly must be distinguished: the negative externalities that might be generated in cases the DOJ loses because of using bright but inexperienced attorneys, and the negative externalities the agency suffers when DOJ refuses to press an argument or pursue litigation to the extent the agency desires. Presumably, the latter externalities include cases the agency otherwise values and might have chosen to litigate.

The first category of losses is probably not large; as noted above, DOJ has relatively high success rates in litigation. E ven if they are large, particularly when coupled with the second type of losses, the political system is unlikely to be able to devise solutions to force DOJ to internalize those costs. First, the obvious solution-to allow agencies the power and funds to hire private counsel or independent litigation authority-is unrealistic. B ecause of congressional control over salaries for government attorneys, it is unlikely agencies will be authorized to hire more experienced or better credentialed attorneys. In short, the agencies may simply be substituting one group of inexperienced attorneys for another less talented group. It is also unlikely that Congress would appropriate large funding increases for agencies to hire more attorneys to staff cases. Indeed, both the level of salaries for federal attorneys and the low number of attorneys (given the amount of the legal work handled in the federal government), suggest that these problems may reflect strong legislative preferences concerning the level of law enforcement desired by Congress. A dd to this the power of the President-with DOJ 's assistance-to oppose decentralization of litigation authority, and the political problems for the agency become almost insurmountable. ${ }^{51}$

A Ithough DOJ authority over litigation arguably may impede presidential initiatives taken by agencies, recent experience suggests that the opposite is

\footnotetext{
This goodwill takes many forms, which manifest themselves in procedural advantages for the government. O ne of the least noticed but important is the ability of the government to bring matters outside the record to the court's attention. Caplan discusses this process of "lodging" of materials with the Supreme Court. See CA PLA N, supra note 32, at 21-24. L ess noticed is the same process that occurs in the courts of appeals. This lodging practice has substantive effect in at least two ways. First, in cases involving review of agency action the government may choose to bring to the court's attention agency past practices or interpretations that argue strongly in favor of deferring to the agency's position. See, e.g., R eply Brief for the A ppellant at 11, A zurin v. V on R aab, 803 F.2d 993 (9th Cir. 1986) (No. 86-2154) (citing Excerpts of R ecord for Customs Service); B rief for the A ppellants at 12, Edwards v. B owen, 785 F.2d 1440 (9th Cir. 1986) ( $N$ o. 85-2060); B rief for Secretary of H ealth \& H uman Services at 15 n.7, H ogan v. H eckler, 769 F.2d 886 (1st Cir. 1985) (No. 85-1149). Second, most judges (even if they are not honest about admitting it) are concerned about the effects or consequences of their rulings. Lodging allows the government to put before the court material that alerts the court to the adverse fiscal or programmatic consequences that may attach to a defeat for the government. In some instances the government may simply inform the court of facts, without even putting matters into the record. See Petition for R eh'g \& Suggestion for R eh'g E n B anc of the U nited States at 13, W est v. U nited States, 744 F.2d 1317 (7th Cir. 1984) (en banc) (N 0. 83-1482).

51. The battle over independent litigation authority and presidential control are canvassed in HOROWITZ, supra note 7, and D evins, U nitariness, supra note 1.
} 
likely to be the case. Where agencies take an initiative that has either the implicit or explicit support of the White House, DOJ opposition is highly unlikely. ${ }^{52}$

3. Government Free-Riding in Cases and the Bipolar Alignment of Litigation. A hidden subsidy for DOJ may arise from the nature of the litigation in which DOJ is involved, as well as the differing resources of the parties. Not all DOJ cases involve disputes with parties who have significant resources to hire private counsel. Indeed, the large percentage of litigation with the federal government are cases at the other extreme, including cases involving Social Security benefits, other social programs, and prisoner litigation. ${ }^{53}$ In this category of cases, D OJ generally has the significant resource advantage over the pro se litigants, legal services attorneys, and solo practitioners. $^{54}$

In the other category of cases, however, DOJ is litigating against both a large, elite law firm and a corporate client or trade association with significant resources for funding litigation. M any major regulatory disputes fall into this category, including environmental regulation, regulation of financial institutions, and workplace and auto safety. Such cases are likely to pit D OJ against a larger and more experienced legal staff. How is D OJ subsidized in these cases?

A t least part of the answer comes from the politics of regulation. Delegation of power to administrative agencies can occur in many different ways, with Congress holding broad powers to design agencies. N ot infrequently, Congress will delegate power to an agency when powerful well-resourced interest groups are in conflict on a policy issue. ${ }^{55}$ The $\mathrm{O}$ ccupational Safety and $\mathrm{H}$ ealth $\mathrm{A}$ dministration ("OSHA"), the National Labor Relations Board, and the National Traffic Safety A dministration fall in this category. In other situations, Congress may delegate power to multiple agencies, with each agency having jurisdiction over a particular interest group. The Comptroller of the Currency (national banks), the National Credit U nion Administration (federal credit unions), and the Securities and Exchange Commission (securities industry) fall within this description. In either regulatory category, however, agency actions that trigger litigation are likely to produce powerful winners and losers. If OSHA adopts a benzene standard for the workplace, both unions and the industry affected will be likely litigants. ${ }^{56}$ If the Comptroller of the Currency lets

52. See CAPLAN, supra note 32 , at 39-48 (discussing W hite H ouse intervention in drafting of brief in Bakke case); id. at 56-57 (discussing W hite H ouse intervention in B ob J ones litigation).

53. See Data U Ser Servs. Div., U.S. Dep't of Commerce, Statistical a bstract of the U NITE D STA TES 216 (1997) (listing number of district court filings).

54. See generally M arc G alanter, Why the "H aves" Come out A head: Speculations on the L imits of L egal Change, 9 L. \& SOC'Y REV. 95, 98-103, 108-10 (1974) (describing the resource advantages of "repeat players" in the justice system).

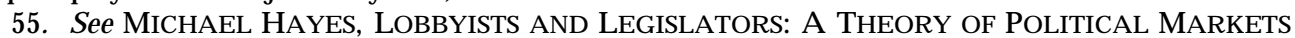
108 (1974); Steven P. Croley, Theories of Regulation: Incorporating the Administrative Process, 98 COLUM. L. REV. 1, 22-24 (1998).

56. See Industrial U nion D ep't, A FL -CIO v. A merican Petroleum Inst., 448 U .S. 607 (1980). 
banks sell annuities, the insurance industry is a likely litigant. ${ }^{57}$ If the E nvironmental Protection A gency adopts a rule insulating secured creditors from liability for environmental cleanup on property, the generous exemptions may prompt litigation by the $C$ hemical $M$ anufacturers $A$ ssociation. ${ }^{58}$

The resulting configuration of litigation usually includes well-financed parties that intervene on the side of DOJ. These parties, represented by law firms comparable to the firms challenging the government's action, can pick up for some of the deficiencies in the government's presentation, particularly in the parts of a case that might include significant devotion of work hours-such as combing through legislative history, reviewing large administrative records, or analyzing technical data. The incentives of the agency and the private intervenors may not always be perfectly aligned, but the intervenors, who often stand to benefit significantly from the agencies' action, are likely to devote substantial resources to marshalling strong legal arguments in the government's favor ${ }^{59}$

Thus, it is a mistake to look at D OJ litigation resources without looking at the broader regulatory and legal context in which these cases arise. Sometimes it is the DOJ attorney-relatively inexperienced and alone on a case-who has the resource advantage over her adversary. O ftentimes, D OJ litigation is simply another stage in the conflict between powerful interest groups. In such cases, DOJ attorneys play a significant role, but often litigate with the support of the interest groups who stand to lose or gain by the outcome of the litigation. It is not uncommon for agencies, because of funding shortfalls that may often be intentional, to depend upon the resources of private interest groups to carry out a regulatory mission. There is no reason that this pattern should abruptly end when the matter is handed over to DOJ for litigation.

4. U nderstanding A dministrative $L$ aw $D$ octrines as a F orm of $L$ egal Subsidy. A cursory glance at many doctrines in administrative law reveals what appears to be a tilt in favor of the government. The government has available a range of jurisdictional defenses that lead to dismissal without any consideration of the merits. The doctrines of exhaustion of administrative remedies, finality, ripeness, and standing frequently are barriers to challenging government

57. See NationsB ank v. V ariable A nnuity Life Ins., 513 U .S. 251 (1995); see also National Credit U nion A dmin. v. First Nat'l Bank \& Trust Co., 118 S. Ct. 927 (1998) (invalidating, at behest of banking industry, agency interpretation of statute authorizing broad geographical expansion by federal credit unions).

58. See Kelley v. Environmental Protection A gency, 15 F.3d 1100 (D.C. Cir. 1994), cert. den. sub nom. A merican B ankers A ss'n v. K elley, 513 U .S. 1110 (1995).

59. A long with an attorney in the Office of the Solicitor General, I prepared the brief for the Comptroller of the Currency in Clarke v. Securities Industry A ss'n, 479 U .S. 388 (1987). The major issue in the case was whether bank discount brokerage offices are "branches" subject to the thenexisting ban on interstate branching found in the M CFadden A ct. In our brief we made strong arguments from the text of the statute and its legislative history. What we failed to develop in our brief was a reference in the legislative history to the long-established practice of bank off-site use of safety deposit boxes, which supported the notion that not all bank offices are branches. The private law firm representing the intervenor on our side (Security Pacific National Bank) discussed this in its brief. The Court's opinion expressly relies upon this passage in the legislative history. See id. at 406. 
actions. These doctrines not only delay litigation, but force the private litigant to expend resources to challenge decisions in the administrative process. ${ }^{60}$ A dditionally, although the standards of review in administrative law differ, they all allow for giving deference to the agency's action. ${ }^{61}$ For example, despite the A dministrative Procedure A ct's authorization of de novo review, it is virtually never applied in practice. ${ }^{62}$ Coupling these deferential standards with the bar against expansion of the administrative record ${ }^{63}$ makes it even more difficult to challenge the agency's decision.

The government's jurisdictional defenses operate with powerful anti-waiver doctrines. A s an interpretive matter, the Supreme Court has repeatedly held that waivers of sovereign immunity are to be strictly construed. ${ }^{64}$ M oreover, insofar as a legal defense of the government can be tied to sovereign immunity, it is considered jurisdictional in nature and not waivable by counsel. ${ }^{65}$ The nonwaiver rules that benefit the government appear particularly odd when compared to the strict waiver rules applicable to private parties who challenge agency action. ${ }^{66}$

No doubt these administrative law doctrines and waiver rules can be persuasively justified on sound constitutional and policy grounds. Indeed, administrative law scholarship is dominated by a discussion of these sorts of issues in a separation of powers context. W hat is suggested here is that these rules operate as a kind of subsidy. Consider the Chevron doctrine. ${ }^{67}$ A s formulated, Chevron requires the reviewing court to ask: first, whether the intent of Congress is clear and thus binding on the agency; second, if the statute is ambiguous, whether the agency's interpretation is reasonable. ${ }^{68}$ The debate over the normative and positive aspects of the Chevron doctrine have been voluminous, with most of the former devoted to debating the separation of powers implications of $\mathrm{Chevron.} \mathrm{My} \mathrm{interest} \mathrm{in} \mathrm{Chevron} \mathrm{is} \mathrm{quite} \mathrm{different.} \mathrm{Chevron-and} \mathrm{the}$

60. See FTC v. Standard Oil Co., 449 U .S. 232, 244 (1980) (holding that the expense of litigation is part of the "social burden" and that there was no irreparable harm in a litigant defending itself in administrative proceedings).

61. See 5 U.S.C. § 706(2) (1994).

62. Seeid. § 706(2)(F); Peter Strauss et AL., Gellhorn \& BySE'S A dministrative La w 939 (1995) (noting that O verton Park "limits de novo review under the [A dministrative Procedure A ct] to very unusual circumstances"). Indeed, even when the administrative record is compiled by the agency in an ex parte proceeding, review is confined to that record. See Franklin Savings A ss' $n$ v. Office of Thrift Supervision, 934 F.2d 1127 (10th Cir. 1991).

63. See Camp v. Pitts, 411 U .S. 138 (1973)

64. See Lane v. Pena, 518 U .S. 187 (1996); Smith v. U nited States, 507 U .S. 197 (1993); see also M assieu v. R eno, 91 F.3d 416, 419-20 (3d Cir. 1996) (stating that the finality requirement for seeking review of agency action is jurisdictional and not subject to waiver).

65. See H enderson v. U nited States, 517 U .S. 654 (1996).

66. See J ones v. Board of G overnors, 79 F.3d 1168 (D.C. Cir. 1996) (stating that a party who does not participate in agency proceeding may not seek judicial review of agency action); Northwest $A$ irlines, Inc. v. Federal A viation A dmin., 14 F.3d 64, 73 (D.C. Cir. 1994) (holding that argument not raised before agency may not be basis for challenge on judicial review).

67. See Chevron, U.S.A., Inc. v. Natural Resource Defense Council, Inc., 467 U .S. 837, 842-43

(1984). For a recent application, see A tlantic M ut. Ins. Co. v. Commissioner, 118 S. Ct. 1413 (1998).

68. See Chevron, 467 U.S. at 841-42. 
general concept of deference to the agency ${ }^{69}$ - significantly decreases the government's litigation burden. The party challenging the agency's decision can prevail if and only if it is shown that the statute clearly addresses the issue adversely to the government. ${ }^{70}$ The DOJ - and the agency-usually can prevail if they can show that the statute is ambiguous. ${ }^{71}$ The different burdens are clear and could have an offsetting effect on DOJ's chances of prevailing and on the amount of work that needs to be devoted to the case. Plainly, for the party challenging the agency, the added burden requires a greater commitment of resources to overcome D O J 's inherent advantage at litigating questions of law. ${ }^{72}$

\section{B. Decentralizing L itigation A uthority: Informational and Institutional Challenges}

The DOJ's firm control of what litigation will be pursued and what arguments will be raised is a mechanism for offsetting the experience and staffing disadvantages under which DOJ operates. Plainly, if one sifts through cases to select those with stronger arguments and higher stakes, better litigation results can be expected. DOJ 's selectivity also creates a pool of goodwill and credibility with courts that enhances the prospects for favorable litigation outcomes. A lthough the agencies are forced to incur the costs of this litigation arrangement, most commentators suggest that agencies either are ambivalent about the arrangement or outright supportive of it because they may at times gain important victories by drawing on the pool of goodwill DOJ creates. $^{73}$ "Overgrazing" of this commons can be prevented only by delegating to DOJ the gatekeeper role.

69. I am aware of an argument that the application of Chevron may in fact lead to more aggressive review of agency decisions. This is particularly the case where step one of Chevron is merged with a textually determinate theory of statutory interpretation. See William N. Eskridge, Jr. \& Philip P. Frickey, The Supreme Court, 1993 Term, Foreword: Law as Equilibrium, 108 HARV. L. REV. 27, 73 (1994); Thomas W. M errill, Textualism and the Future of the Chevron D octrine, 72 W A SH. U . L.Q. 351 (1994); Nicholas S. Z eppos, J udicial Review of A gency Action: The Problems of Commitment, NonContractability, and the Proper Incentives, 1995 DUKE L.J. 1133, 1143. This debate is irrelevant for present purposes because I am using Chevron as shorthand for giving the agency great deference in interpreting statutes. See Smiley v. Citibank, N.A ., 116 S. Ct. 1730 (1996).

70. A party may still prevail if it shows that the agency acted unreasonably under step two of Chevron. See R onald M. L evin, The A natomy of Chevron: Step T wo Reconsidered, 72 CHI.-K ENT L. REV. 1253 (1997). H owever, like step one, this standard of review typically tilts in favor of the government.

71. See A tlantic M ut. Ins. Co., $118 \mathrm{~S}$. Ct. at 1418 ("Since the term 'reserve strengthening' is ambiguous, the task that confronts us is to decide, not whether the Treasury regulation represents the best interpretation of the statute, but whether it represents a reasonable one." ). Chevron cases raise interesting strategic decisions for DOJ and agency lawyers. A $n$ agency may well prefer to win cases at Chevron step two because if it wins at step one it cannot alter its decision in the future, a course of action not unusual for agencies. Thus, in briefs D OJ attorneys ultimately may argue that, while the statute clearly supports the agency, it is sufficient to resolve the case to hold simply that the statute is ambiguous, and the agency's reading reasonable.

72. Cf. POSNER, supra note 45, at 176 (noting that Chevron doctrine lowers decision costs for judges reviewing agency interpretations).

73. See HOROWITZ, supra note 7, at 45; Herz, supra note 7, at 160. 
Even if we accept part of this argument-that a pool of goodwill is created-is it possible that under an alternative litigating structure goodwill could also be created? Suppose Congress entirely decentralized litigation authority among government agencies; presumably, some agencies would see an advantage in mimicking D OJ litigation structures, thereby creating their own agencyspecific goodwill. A gencies could (and some with independent litigation authority have) set up litigation structures that include trial, appellate, and Supreme Court experts. J ust as D OJ strictly controls which cases are pressed and which arguments are raised, the agency lawyers would play gatekeeper at each stage of the case.

There are several reasons why this decentralized system may not work to produce pools of goodwill, and why some institutional actors may prefer the DOJ monopoly. First, individual members of Congress might skew the system. In a decentralized Congress, independent litigation authority may give individual members with a strong interest in pending matters an incentive to distort the agency's litigation decisions, thus impeding the effort to create agencyspecific goodwill with the courts. ${ }^{74}$ In a battle with a powerful committee chair, an agency general counsel's plea that a matter might undermine the agency's credibility with the court is not likely to be considered seriously. Particularly for a member of Congress on a two-year election cycle, an agency's long-term relationship with the courts is not likely to count for much. ${ }^{75} \mathrm{~A} n$ additional factor is the agency's inability to stand with the full support of the A ttorney G eneral and the President. When the A ttorney G eneral or one of her subordinates speaks to a powerful member of Congress, each side knows that ultimately the President can be enlisted (or already has been) to support the litigation decision. The member knows that a fight with the President is a far different matter than a dispute with an agency general counsel cut off from the D OJ/presidential power structure. ${ }^{76}$

Opposition to the decentralized litigation system is likely to come from a more important institution, the federal judiciary. Since federal judges are both the dispensers and one of the benefactors of litigation goodwill, their opposition would be pivotal. The DOJ monopoly and screening produces important benefits for the judiciary: It reduces caseload, ensures a constant stream of intellectually challenging and important cases, and warrants that issues were vet-

74. See CLAYTON, supra note 1, at 9 (discussing Congress's preference for independent litigation authority as a means of enhancing legislative power). The Supreme Court has explicitly stated its skepticism that agencies would forbear from "unnecessary" litigation. See Federal Election Comm'n v. NRA Political Victory Fund, 513 U.S. 88, 96 (1994) (noting that, absent Solicitor General control, agencies would press a "more parochial view"); U nited States v. Providence J ournal C 0., 485 U .S. 693, 701 (1988) (commenting on "parochial interests of a particular agency").

75. See Herz, supra note 7 , at 143 (discussing multiple constituencies of agency general counsel and need for working relationship with congressional committees); cf. Pillsbury Co. v. FTC, 354 F.2d 952 (5th Cir. 1966) (vacating agency order on grounds that Senate subcommittee deprived Pillsbury of procedural due process and remanding case to the FTC).

76. See Peter L. Strauss, The Place of Agencies in Government: Separation of Powers and the Fourth Branch, 84 COLUM. L. REV. 573, 590-94 (1984). 
ted and that only important and serious arguments are pressed, thus allowing the court to conserve precious resources. In short, D O J's signature on a brief constitutes important information upon which the court relies. In exchange, of course, the court gives D OJ goodwill. Indeed, at the Supreme Court, this trade is explicitly acknowledged, and when the Solicitor General reneges, the Court has not hesitated to rebuke the Solicitor $\mathrm{G}$ eneral and remind him of his obligations. $^{77}$

When we decentralize litigation authority, the judicial branch bears extra costs. M ost importantly, the courts would have to undertake an agency-specific calculation of whether DOJ -type screening is being done, at what level, and in turn what goodwill if any to give the agency. Given the number of federal agencies, this search, evaluation, and assessment can be time consuming and costly for the courts. ${ }^{78}$ Of course, each agency would try to project to the courts that they are engaged in D OJ -type screening processes. If, because of the costs of assessment and valuation, the judiciary was unable to detect which agencies were truly undertaking the screening, a "lemons" problem would arise. ${ }^{79}$ The courts, as "purchasers" of screening, could not detect which agencies were screening and therefore would simply stop "paying" out goodwill. A gencies would also respond rationally; because courts were not offering goodwill, there would be no point to competing with the other agencies to earn goodwill. UItimately, therefore, the entire system would bear more costs, with higher caseloads, more careful scrutiny of government arguments by the courts, and potentially greater resources devoted to government lawyering to make up for the loss of goodwill.

Even if the result is not the inability to detect which agencies are selling "lemons," the courts are unlikely to embrace the decentralized litigation plan. The judiciary, as does DOJ, gains enormous benefit from D OJ's screening of cases and arguments. M ore time is made available to devote to opinion quality, oral argument preparation, judicial administration, or even leisure time for judges interested in using their time otherwise. ${ }^{80}$ For judges as much as DOJ lawyers, the challenge and intellectual stimulation of the cases that arise from the centralized plan contributes not only to job satisfaction, but to prestige as

77. On two recent occasions, the Solicitor General supported arguments making inroads into his control over Supreme Court litigation, and in both cases the Court rejected the arguments. See NRA, 513 U .S. at 99; Providence J ournal Co., 485 U.S. at 701. The Court explicitly chastized the Solicitor General's ceding of power, "find[ing] such a proposition somewhat startling, particularly when supported by the office whose authority would be substantially diminished by its adoption. ..." Providence J ournal C $0 ., 485$ U.S. at 701.

78. DOJ represents over 100 federal agencies. See DOJ LEGAL A CTIVITIES, supra note 5, at 37. In this respect, the problems associated with all government agencies "owning" litigation rights may be analogized to a tragedy of the "anticommons." See M ichael A. Heller, The Tragedy of the A nticommons: Property in the Transition from M arx to M arkets, 111 H A R V. L. R EV . 621 (1998).

79. See George A. A kerlof, The Market for "Lemons": Quality, Uncertainty, and the Market M echanism, 84 Q.J. E CON. 488 (1970).

80. See POSNER, supra note 45 , at $117-44$ (offering model of judicial utility function). 
well. ${ }^{81}$ Federal judges, many of whom have D OJ experience, continue to be direct beneficiaries of D OJ's monopoly.

The difficulty of generating agency-specific goodwill is further underscored by the fact that not all government agencies regularly litigate before the Supreme Court and courts of appeals. The earning of a reputation, however, requires that the game between court and litigator be a repeated one. ${ }^{82}$ If the agency knows that it is an infrequent litigant it may have no incentive to earn goodwill, or if it does it may fear that its showing of restraint will go unrewarded, since the court will rationally conclude that it will be unable to reward or penalize. Centralization of litigation overcomes this problem and allows all agencies to share in the potential for goodwill created by D OJ. ${ }^{83}$

IV

\section{CONCLUSION}

This essay offers a preliminary analysis of an aspect of D OJ representation that has largely been ignored. The narrow problem of DOJ staffing of cases

81. See Harry T. Edwards, The Rising Work L oad and Perceived "Bureaucracy" of the Federal Courts: A Causation-Based A pproach to the Search for A ppropriate Remedies, 68 IOWA L. REV. 871, 918 (1983); Carolyn Dineen K ing, A M atter of Conscience, 28 H OU S. L. REV. 955, 959 (1991). For an extended discussion of the problem of the growing federal caseload, see RICHARD A. POSNER, THE FEDERAL COURTS: CRISISAND REFORM (1985), and the more muted concerns in POSNER, supra note 45.

82. See Robert A xelrod, The Evolution of CoOperation 16 (1984). This explains how certain agencies with independent litigation authority manage to become repeat litigants (particularly before the D.C. Circuit) and attempt to develop goodwill. For example, the SE C and FCC frequently appear with their own counsel in the D.C. Circuit and the judges on that court may obtain sufficient information, along with the possibility of a repeated game, to establish levels of goodwill. Notice, however, while one can speculate that these agencies with independent litigation authority can effectively mimic the DOJ litigation model and develop similar reputations, anecdotal evidence suggests the contrary. The Office of Thrift Supervision ("OTS"), which regulates savings and loans, has established a horrible litigation reputation in the D.C. Circuit. See K aplan v. OTS, 104 F.3d 417, 424 (D.C. Cir. 1997) ("OTS' position in this case comes perilously close to treating those who serve on the boards of both savings and loans and their parents as absolutely liable. ... This will not do as a matter of administrative law."); J ohnson v. OTS, 81 F.3d 195, 203 (D.C. Cir. 1996) (characterizing agency position as "nonsensical ... it proves almost nothing"); W achtel v. OTS, 982 F.2d 581, 585 (D.C. Cir. 1993) (refusing to defer to agency position that is "almost frivolous"); see also Checkosky v. SE C, 139 F.3d 221 (D.C. Cir. 1998) (castigating agency position as "fail[ing] to adopt an intelligible negligence standard," violating "elementary administrative norms of fair notice and reasoned decisionmaking," and finding agency opinion "almost deliberately obscurantist"). Perhaps even more startling, some agencies with independent litigation authority have, on occasion, explicitly disclaimed any special relationship between government counsel and the judiciary. See Freeport-M CM oR an Oil \& Gas Co. v. Federal E nergy R egulatory Comm'n, 962 F.2d 45, 46 (D.C. Cir. 1992) (“W e... pause to address FE R C counsel's remarkable assertion at oral argument that government attorneys ought not be held to higher standards. .."). H owever, the court has reminded government counsel of their higher obligation. See id. at 48 ("We find it astonishing that an attorney for a federal administrative agency could so unblushingly deny that a government lawyer has obligations that might sometimes trump the desire to pound an opponent into submission." ).

83. Consider the recent case of $\mathrm{N}$ ational Credit $\mathrm{U}$ nion $\mathrm{A}$ dmin. v. First $\mathrm{N}$ at'I B ank \& Trust C $0 ., 118$ S. Ct. 927 (1998). There, the Solicitor G eneral represented the National Credit U nion A dministration ("NCUA") on an important question of banking law. The NCUA rarely litigates in any courtespecially the Supreme Court-and thus had little opportunity to develop a litigation reputation. E ven though the NCUA was unsuccessful in this case, by being represented by the Solicitor General the agency was able to draw on the goodwill. 
and hiring of attorneys raises complex and difficult questions of administrative regulation, professional responsibility, and economics. The story told here is subject to a number of important caveats, which, I hope, do not unduly detract from the argument pressed. More empirical data is needed on numerous aspects of the problem, including tenure for D OJ attorneys, work assignments for DOJ and private lawyers, and actual control of DOJ litigation. A dditionally, the argument is necessarily incomplete because it largely ignores separation of powers issues and questions of bureaucratic governance. The discussion has also glossed over a number of important distinctions among agency lawyers and litigating offices within DOJ. Given my interest in setting forth a general problem and a broad theoretical framework, it would not be surprising that other areas of government litigation would fall far outside the discussion.

D espite this essay's limitations, it is clear that DOJ recruiting, staffing of cases, and work assignments warrant further attention. Scholars who have contributed significantly to the debates over the role DOJ plays in separation of powers battles or disputes over regulatory reform should not be surprised to discover that there are important aspects of the government lawyering process that remain unexplored. Indeed, with DOJ playing such a pivotal role in the administrative state, it would be surprising if we were to learn otherwise. 